\title{
Phenolic Composition and Inhibitory Ability of Methanolic Extract from Pumpkin (Cucurbita pepo L) Seeds on Fe-induced Thiobarbituric acid reactive species in Albino Rat's Testicular Tissue In-Vitro
}

\author{
Seun F. Akomolafe ${ }^{1 *}$, Ganiyu Oboh $^{2}$, Sunday I. Oyeleye ${ }^{2,3}$, Olorunfemi R. Molehin ${ }^{1}$, Opeyemi B. Ogunsuyi ${ }^{2,3}$ \\ ${ }^{1}$ Department of Biochemistry, Ekiti State University, Ado-Ekiti, Nigeria P.M.B., 5356, Nigeria. ${ }^{2}$ Nutraceutical and Phytomedicine unit of Biochemistry \\ department, Federal University of Technology, Akure, Nigeria P.M.B., 704, Akure, Nigeria. ${ }^{3}$ Department of Biomedical Technology, Federal University of \\ Technology, Akure, Nigeria P.M.B., 704, Akure 340001, Nigeria.
}

\begin{tabular}{l} 
ARTICLE INFO \\
\hline Article history: \\
Received on: $24 / 12 / 2015$ \\
Revised on: $11 / 04 / 2016$ \\
Accepted on: $07 / 06 / 2016$ \\
Available online: $26 / 09 / 2016$ \\
\hline
\end{tabular}

Key words:

Pumpkin seed, oxidative stress, testicular disease, Phenolic compounds.

\begin{abstract}
Pumpkin seed has been associated with myriad of medicinal uses in different part of the world. In this study, phenolic composition and $\mathrm{Fe}^{2+}$ induced thiobarbituric acid reactive species (TBARS) inhibitory ability of methanolic extract from pumpkin seeds in rat's testes homogenates were determined. The extract was prepared with 80\% methanol (v/v) and the radicals [(1,1-diphenyl-2 picrylhydrazyl (DPPH), 2,2'-azino-bis(3ethylbenzthiazoline-6-sulphonic acid) (ABTS)] scavenging, $\mathrm{Fe}^{2+}$ chelation and ferric reducing abilities of the extract were carried out. The phenolics composition was also investigated using gas chromatography couple with flame ionization detector (GC-FID). The GC analysis revealed the presence of vallinic, coumaric protocatechuic, caffeic, ferulic and sinapinic acids, and apigenin, quercetin, luteolin, kaempferol as the dominant phenolic compounds. The results revealed that the extract inhibited $\mathrm{Fe}^{2+}$-induced TBARS, scavenge DPPH radical and chelate $\mathrm{Fe}^{2+}$ in a dose dependent manner. The extract also scavenged ABTS radical and reduced $\mathrm{Fe}^{2+}$ to $\mathrm{Fe}^{3+}$. Although, the standard used had higher effect compared to the extract, nevertheless, the TBARs inhibitory potential of the extracts clearly gives an insight on the protective potentials against oxidative induce testicular damage that might lead to male infertility if unchecked. These abilities could however be linked to the presence of polyphenolic compounds.
\end{abstract}

\section{INTRODUCTION}

Oxidative stress (OS), which can be defined as increase free radical production or reduce antioxidant defence system has been intensely study and reported as major factor in the pathogenesis of male infertility (Köksal et al., 2000; Ishikawa et al., 2007; Mostafa et al., 2009; Abd-Elmoaty et al., 2010; Akomolafe et al., 2015). Malondialdehyde (MDA), a by-product of lipid peroxidation, is among the major laboratory tests in the measurement of OS, and can be easily measure by the determination of thiobarbituric acid reactive species (TBARs) assay; a major reactive species produced when radicals attack

\footnotetext{
* Corresponding Author

E-mail: purposefulseun @yahoo.co.uk

Tel. no: +2348030460149
}

and degrade polyunsaturated fatty acids (PUFAs) (Yagi, 1998; Akomolafe et al., 2015; Adedayo et al., 2015a), and its capable of inducing toxic stress in the cells and form advanced glycation endproducts (Nowotny et al., 2015). Transitional metals such as Iron (Fe) has been reported as one of the essential metals, required as the physiological component of many enzymes and proteins (Khan and Awan, 2014), but its free form in the biological system has been reported to cause considerable oxidative damage via induction of radicals production, and biomolecules (lipids, nucleic acids and proteins) oxidation which could result to wide range of impairment to cellular function and integrity (Khan and Awan, 2014). However, consumption of phenolic-rich plants and/or its extracts has been reported to ameliorate OS, and could be due to their richness in natural antioxidant agents such as phenolic compounds (Schiffrin, 2010; Ademiluyi et al., 2014). 
The importance of antioxidant compound and the management of several human diseases have attracted much research attention recently (Skotti et al., 2014). According to Farombi and Olatunde (2011) and Atangwho et al. (2013), the use of medicinal plant/extract in the management of some ailments in folklore is a major practice, especially in the developing countries. And several reports have logically linked the nutraceutical values provided by the consumption of plant based food/extracts against several human diseases to the presence of antioxidants and phytochemicals such as vitamins $\mathrm{C}, \alpha$-tocopherol, $\beta$-carotene and polyphenols (Fasakin et al., 2011; Adedayo et al., 2015a,b).

Cucurbita pepo Linn (Family: Cucurbitaceae), also known as pumpkin in English and locally called "Elegede" is a popular plant in the Southwest Nigeria (Oloyede, 2012). The young leaf that is locally called "Gboro" is commonly consumed while the pulp of ripe fruits has been reported for its use in the management of intestinal inflammation, stomach and liver disorders and as dietary supplement for vitamin A (Sarkar and Guha, 2008). The seeds, otherwise known as pepitas, are small flat, green edible seeds that are often recommended as dietary supplement and for the management of certain digestive ailments such as constipation and diarrhea in folklore medicine. In this study, we aim to investigate the protective ability of the methanolic extract from the pumpkin seed against Fe-induced TBARs production in albino rat's testicular tissue in-vitro. The ability of the extract to scavenge radicals, chelates $\mathrm{Fe}^{2+}$ and reduced $\mathrm{Fe}^{2+}$ to $\mathrm{Fe}^{3+}$ were also investigated.

Phenolic compositions of the extract were also determined using gas chromatography coupled with flame ionization detector (GC-FID).

\section{MATERIALS AND METHODS}

\section{Chemicals and reagent}

All chemicals and reagent used were of analytical grade and glass-distilled water was used. Kenxin refrigerated centrifuge Model KX3400C was use while UV-Visible spectrophotometer (Model 6305; Jenway, Barloworld Scientific, Dunmow, United Kingdom) was used to measure the absorbance.

\section{Samples collection and preparation of extract}

Fresh Pumpkin fruits were harvested from a local farm in Akure metropolis, Nigeria. Authentication of the sample was carried out at the Department of Plant Science, Ekiti State University, Ado-Ekiti, Nigeria by Mr. Ajayi (the herbarium curator). The voucher specimen number given was UHAE 332. The seeds were carefully removed with table knife, washed with distilled water and dried to constant weight in oven at $40{ }^{\circ} \mathrm{C}$. Thereafter, the seeds was grounded to powdered and soaked in hexane to remove the fat and dried. The methanolic extraction was carried using the method of Chu et al., (2002). Ten gramme of the pulverized sample was extracted with $100 \mathrm{~mL}$ of absolute methanol and was filtered (Whatman no. 2) under vacuum after 24 h. The filtrate was evaporated using a rotary evaporator under vacuum at $45{ }^{\circ} \mathrm{C}$. The extract was stored under refrigeration for subsequent analysis.

\section{Determination of total phenol content}

Total phenol content was determined using FolinCiocalteau's reagent method (Singleton et al., 1999). Briefly, appropriate dilution of the extract was oxidized with 2.5 $\mathrm{mL}$ of $10 \%$ Folin-Ciocalteau's reagent $(\mathrm{v} / \mathrm{v})$ and neutralized with $2.0 \mathrm{~mL}$ of $7.5 \%$ sodium carbonate. The reaction mixture was incubated for $40 \mathrm{~min}$ at $45^{\circ} \mathrm{C}$ and the absorbance was measured thereafter at $765 \mathrm{~nm}$. The total phenol content was subsequently calculated and presented as gallic acid equivalents (GAE).

\section{Determination of total flavonoid content}

Determination of total flavonoid content was carried out using a slightly modified method of Meda et al., (2005). $0.5 \mathrm{~mL}$ of appropriately dilutions of the extract was mixed with $0.5 \mathrm{~mL}$ of absolute methanol, $50 \mu \mathrm{L}$ of $10 \% \mathrm{AlCl}_{3}, 50 \mu \mathrm{L}$ of $1 \mathrm{M}$ Potassium acetate and $1.4 \mathrm{~mL}$ of distilled water. The mixture was incubated at room temperature for $30 \mathrm{~min}$. The absorbance of the mixture was subsequently measured at $415 \mathrm{~nm}$. The total flavonoid content was calculated and presented as quercetin equivalents $(\mathrm{QE})$.

\section{GC-FID characterization of constituent phenolics in the methanolic extract of pumpkin seeds}

The qualitative-quantitative analysis of the phenolic compounds of the sample was carried out using the method reported by Kelley et al., (1994). The phenolic extract was extracted as described by Kelley et al., (1994) and Provan et al., (1994) and the purified phenolic extracts (1 ml: 10:1 split) were analyzed for composition by comparison with phenolic standards (Aldrich Chemical Co., Milwaukee, W1) on a Hewlett-Packard 6890 gas chromatography (Hewlett-Packard Corp., Palo Alto, CA) equipped with a derivatized, non-packed injection liner, a Rtx5MS (5\% Diphenyl-95\% Dimethyl polysiloxane) capillary column (30 m length, $0.25 \mathrm{~mm}$ film thickness), and detected with a flame ionization detector (FID). The following conditions were employed; injector temperature, $23^{\circ} \mathrm{C}$; temperature ramp, $80^{\circ} \mathrm{C}$ for $5 \mathrm{~min}$ then ramped to $250^{\circ} \mathrm{C}$ at $30^{\circ} \mathrm{C} / \mathrm{min}$; and a detector temperature of $320^{\circ} \mathrm{C}$

\section{Lipid peroxidation and Thiobarbituric acid reactions assay}

Wister male albino rat (weighing $205 \mathrm{mg}$ ) was decapitated under mild diethyl ether and the testes tissue was rapidly isolated. The tissue was placed on ice, weighed and subsequently homogenized in cold saline $(1 / 10 \mathrm{w} / \mathrm{v})$ with about 10-up-and - down strokes at approximately $1200 \mathrm{rev} / \mathrm{min}$ in a Teflon glass homogenizer. The homogenate was centrifuged for 10 min at $3000 \mathrm{x} g$ to yield a pellet that was discarded (Belle et al., 2004). Hundred microliter of the supernatant fraction was mixed with a reaction mixture containing $30 \mu \mathrm{L}$ of $0.1 \mathrm{M} \mathrm{pH} \mathrm{7.4} \mathrm{Tris-}$ $\mathrm{HCl}$ buffer, extract $(0-100 \mu \mathrm{L})$ and $30 \mu \mathrm{L}$ of freshly prepared $250 \mu \mathrm{M}$ FeSO4. The volume was made up to $300 \mu \mathrm{L}$ with distilled water before incubation at $37^{\circ} \mathrm{C}$ for $1 \mathrm{~h}$. The colour reaction was 
developed by adding $300 \mu \mathrm{L} 8.1 \%$ sodium dodecyl sulphate to the reaction mixture. $500 \mu \mathrm{L}$ of acetic acid/ $\mathrm{HCl}(\mathrm{pH} 3.4)$ mixture and $500 \mu \mathrm{L}$ of $0.8 \%$ thiobarbituric acid was subsequently added. The mixture was incubated at $100^{\circ} \mathrm{C}$ for $1 \mathrm{~h}$. Ethylenediaminetetraacetic acid (EDTA) was used as control. TBARs produced were measured at 532nm (Ohkawa et al., 1979).

\section{Free radical scavenging ability}

Ability of the extract to scavenge DPPH free radical was evaluated (Gyamfi et al., 1999). In brief, appropriate dilution of the extract or Vitamin C $(1 \mathrm{~mL})$ was mixed with $1 \mathrm{~mL}$ of $0.4 \mathrm{mM}$ methanolic solution of DPPH radical, the mixture was left in the dark for $30 \mathrm{~min}$ and the absorbance was taken at $516 \mathrm{~nm}$. The DPPH radical scavenging ability was subsequently calculated.

\section{Total antioxidant power}

Total antioxidant power of the extract was assessed using the ABTS radical model as described by Re et al., (1999). The ABTS radical was generated by reacting $7 \mathrm{mmol} / \mathrm{l}$ of ABTS aqueous solution with $2.45 \mathrm{mmol} / \mathrm{l}$ of $\mathrm{K}_{2} \mathrm{~S}_{2} \mathrm{O}_{8}$ solution in the dark for $16 \mathrm{~h}$ and adjusting the Abs734 $\mathrm{nm}$ to 0.700 with ethanol. Two hundred microliter of the appropriate dilution of the extract was added to $2.0 \mathrm{~mL}$ ABTS radical solution and the absorbance was measured at $734 \mathrm{~nm}$ after $15 \mathrm{~min}$. The trolox equivalent antioxidant capacity was subsequently calculated.

\section{$\mathrm{Fe}^{2+}$ chelating ability}

The extract ability to chelate $\mathrm{Fe}^{2+}$ was determined using the method of Puntel et al., (2005) with some modifications. A 500 $\mathrm{mmol} / \mathrm{L}$ of freshly prepared $\mathrm{FeSO}_{4}(150 \mathrm{~mL})$ was added to the mixture containing $168 \mathrm{~mL}$ of $0.1 \mathrm{~mol} \mathrm{~L}$ Tris- $\mathrm{HCl}$ (pH 7.4), 218 $\mathrm{mL}$ saline and the extract or ethylenediaminetetraacetic acid (EDTA) $(0-100 \mu \mathrm{L})$. The mixture was incubated for $5 \mathrm{~min}$ and then $13 \mathrm{~mL}$ of $0.25 \% 1,10$-phenanthroline $(\mathrm{w} / \mathrm{v})$ was added. The absorbance was measured at $510 \mathrm{~nm}$ in a spectrophotometer. The percentage of chelated Fe was subsequently calculated

\section{Determination of reducing property}

The reducing property was determined by assessing the ability of the extract to reduce $\mathrm{FeCl}_{3}$ solution as described by Oyaizu, (1986). $2.5 \mathrm{~mL}$ aliquot was mixed with 2.5 $\mathrm{mL} 200 \mathrm{mM}$ sodium phosphate buffer (pH 6.6) and $2.5 \mathrm{~mL} 1 \%$ potassium ferricyanide. The mixture was incubated at $50{ }^{\circ} \mathrm{C}$ for 20 min. and then $2.5 \mathrm{~mL}$ of $10 \%$ trichloroacetic acid was added. This mixture was centrifuged at $650 \mathrm{rpm}$ for $10 \mathrm{~min}$. $1 \mathrm{~mL}$ of the supernatant was mixed with an equal volume of distilled water and $0.2 \mathrm{~mL}$ of $0.1 \%$ ferric chloride. The absorbance was measured at $700 \mathrm{~nm}$. The ferric reducing antioxidant property was subsequently and presented as ascorbic acid equivalent.

\section{Data analysis}

The results of the triplicate experiments were pooled and expressed as mean \pm standard deviation (SD). One way analysis of variance and the least significance difference (LSD) was carried out. Significance was accepted at $\mathrm{P}<0.05$.

\section{RESULTS}

The total phenolic (phenol and flavonoid) content in the methanolic extract from pumpkin seed is presented in Table 1. The total phenol and total flavonoid contents of the extract reported as gallic acid equivalent (GAE) and quercetin equivalent (QE) were $32.90 \mathrm{mg}$ GAE$/ \mathrm{g}$ and $21.50 \mathrm{mg} \mathrm{QE} / \mathrm{g}$ respectively. The GC phenolics profile of the extract is presented in Tables 2. As shown in Table 2, the result revealed the presence of some phenolic acids and flavonoids predominantly were $P$-hydroxybenzaldhyde (6.69 $\mathrm{mg} / 100 \mathrm{~g})$, protocatechuic acid (100.23 mg/100 g), p-coumaric acid $(119.68 \mathrm{mg} / 100 \mathrm{~g})$, vanillic acid $(415.35 \mathrm{mg} / 100 \mathrm{~g})$, caffeic acid (139.71 mg/100 g), sinapinic acid (45.23 mg/100 g), ferulic acid (111.98 mg/100 g), apigenin (28.99 mg/100 g ), kaempferol $(48.81 \mathrm{mg} / 100 \mathrm{~g})$, luteolin $(12.68 \mathrm{mg} / 100 \mathrm{~g})$, quercetin $(60.85$ $\mathrm{mg} / 100 \mathrm{~g})$, Myricetin $(2.28 \mathrm{mg} / 100 \mathrm{~g})$.

Table 1: The total phenol and flavonoid contents, reducing property (FRAP) and ABTS radical scavenging ability of methanolic extract from Pumpkin seed.

\begin{tabular}{ll}
\hline Parameter & Extract \\
\hline Total phenolic content (mg GAE/g) & $32.90 \pm 3.03$ \\
Total flavonoid content (mg QE/g) & $21.50 \pm 0.90$ \\
ABTS radical scavenging ability (mmol.TEAC/g) & $3.90 \pm 0.73$ \\
FRAP (mg AAE/g) & $8.67 \pm 1.24$ \\
\hline
\end{tabular}

Values represent Mean \pm Standard deviation of triplicate experiments.

Table 2: The main phenolic constituents of the methanolic extract from pumpkin seeds.

\begin{tabular}{lc}
\hline Polyphenols & Amount $(\mathbf{m g} / \mathbf{1 0 0}$ g) \\
\hline Protocatechuic acid & $100.23 \pm 2.12$ \\
P-coumaric acid & $119.68 \pm 4.41$ \\
Vanillic acid & $415.35 \pm 2.44$ \\
Caffeic acid & $139.71 \pm 1.32$ \\
Sinapinic acid & $45.23 \pm 1.45$ \\
Ferulic acid & $111.98 \pm 3.21$ \\
Apigenin & $28.99 \pm 0.89$ \\
Kaempferol & $48.81 \pm 1.29$ \\
Luteolin & $12.68 \pm 0.76$ \\
Quercetin & $60.85 \pm 1.23$ \\
Myricetin & $2.28 \pm 0.22$ \\
\hline
\end{tabular}

Values represent Mean \pm Standard deviation of triplicate readings.

As shown in Fig. 1, incubation of testes homogenate with $\mathrm{Fe}^{2+}$ solution caused a significant increase in malondialdehyde (MDA) content to $166.89 \%$ (Induced) as against the basal (100\%) However, addition of the extract (0.83 $-1.67 \mathrm{mg} / \mathrm{mL})$ and/or EDTA (1.56-6.25 $\mu \mathrm{g} / \mathrm{mL})$ in a dose dependent manner caused a significant decrease in the MDA content in the testes homogenate. The DPPH and ABTS radicals scavenging abilities of the extract were presented in Fig. 2 and Table 1 respectively. The result revealed that the extract scavenged DPPH radicals in a dose dependent manner at the concentrations tested $(50-200 \mu \mathrm{g} / \mathrm{mL})$. The ABTS radical (ABTS*) scavenging ability presented as trolox equivalent antioxidant capacity (TEAC) is presented in Table 1. The extract was able to scavenge ABTS* (3.90 mmol TEAC/g). The $\mathrm{Fe}^{2+}$ chelating ability of the extract and EDTA is presented in Fig. 3. EDTA had higher chelating ability of $89.5 \%$ while that of 
the extract was $63.7 \%$ at the highest concentration used. The result of the ferric reducing antioxidant power (FRAP) of the extract was presented as ascorbic acid equivalent in Table 1. The extract exhibited ferric reducing antioxidant power of $8.67 \mathrm{mg} \mathrm{AAE} / \mathrm{g}$.

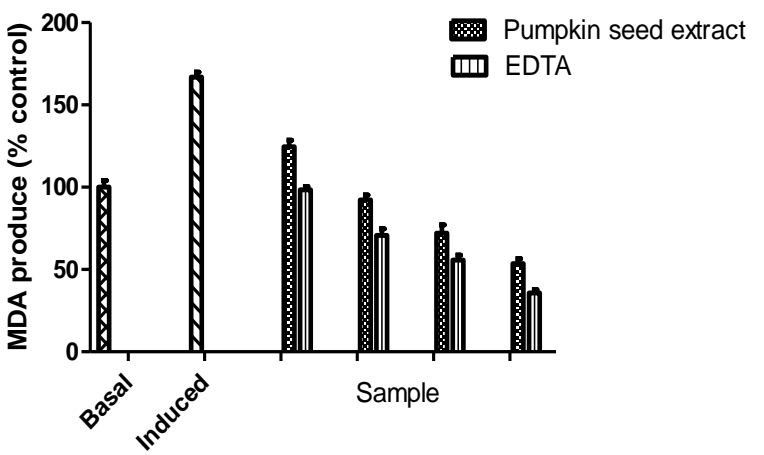

Fig. 1: Inhibition of $\mathrm{Fe}^{2+}$ induced lipid peroxidation in rat testes tissue homogenate by the pumpkin methanolic extract and EDTA. The concentrations of the extract used for the plot of the graph are $0.83,1.00,1.25$ and 1.67 $\mathrm{mg} / \mathrm{mL}$. The concentrations of the EDTA used for the plot of the graph are $1.56,3.13,4.69$ and $6.25 \mu \mathrm{g} / \mathrm{mL}$. Values represent mean \pm standard deviation of triplicate experiments.

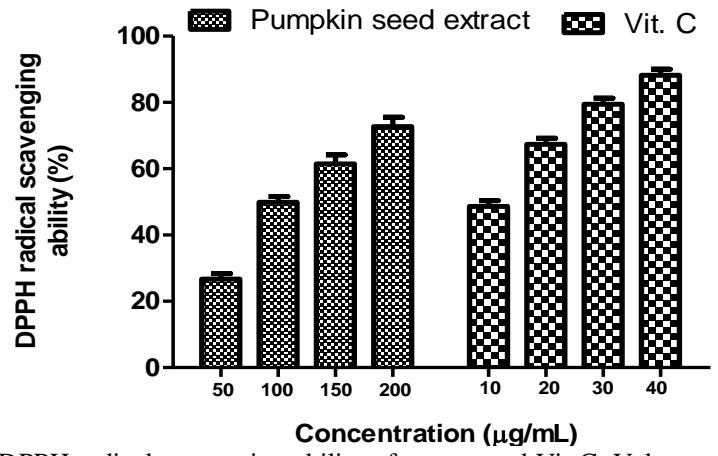

Fig. 2: DPPH radical scavenging ability of extract and Vit C. Values represent mean \pm standard deviation of triplicate experiments.

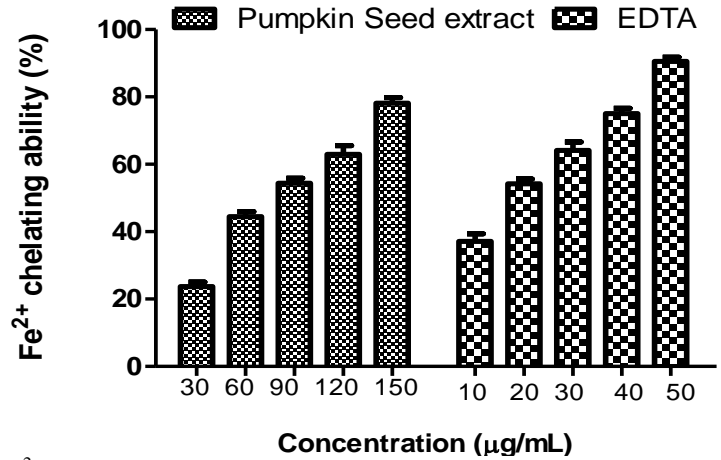

Fig. 3: $\mathrm{Fe}^{2+}$ chelation ability of the extract and EDTA. Values represent mean \pm standard deviation of triplicate experiments.

\section{DISCUSSION}

Recently, research on polyphenolic compounds has become subject of interest as a result of their numerous health benefits (Skotti et al., 2014). Several reports have linked the antioxidant activities of many plant foods/extracts to the polyphenolic compounds, and its believed to be due to the redox properties of their polyhydroxyl molecule, which is known for their ROS adsorbing and neutralizing potentials, chelating of transitional metal catalysts and activation antioxidant enzymes activities (Dai and Mumper, 2010; Tsao, 2010; Tulio et al., 2014). The total phenol and flavonoid contents of the extract are presented in Table 1, as gallic acid (GAE) and quercetin (QE) equivalent respectively. The studied extract had higher total phenol content than total flavonoid (Table 1). This study is in consistence with several reports of some tropical plants with similar trends between the total phenol and flavonoid content (Gacche et al., 2010; Handique et al., 2012; Radojkovic et al., 2012). The use of chromatography analysis to quantify and qualify phenolic profile of plant material has proven to be more advantageous over total phenolic content determination using Folin Ciocalteu method, as it reveals accurate information of individual compounds (Nwanna et al., 2016). The result of the phenolic composition using GC-FID revealed the presence of dominant eleven phenolic compounds of which six were phenolic acids while the remaining five were flavonoids (Table 2). This however, suggests that the extract is rich in phenolics. Phenolics are secondary metabolites and their consumption in phenolic-rich plant foods have been linked to numerous health benefits such as anti-bacterial, ant-glycemic, antiviral, carcinogenic, antiinflammatory and, vasodilatory properties and prevention of lipid peroxidation, a key process in the onset and progression of many degenerative diseases (Dryden et al., 2006; Pandey and Rizvi, 2009; Skotti et al., 2014). Hence, the phenolic constituent in this studied extract could therefore be responsible for the observed biological activities.

One of the major mechanisms of cell injury in aerobic organisms subjected to oxidative stress is lipid peroxidation of biological membranes (Pandey and Rizvi, 2009). The effect of the extract on $\mathrm{FeSO}_{4}$ - induced TBARS production in the isolated rat testes homogenates is presented in Fig. 1. The result revealed that incubation of the testes tissue homogenates with $250 \mu \mathrm{M} \mathrm{FeSO}{ }_{4}$ caused a significant $(p<0.05)$ increase in TBARS content. Several report have shown that $\mathrm{Fe}^{2+}$ can catalyze one-electron transfer reactions that generates reactive species, such as $\mathrm{OH}$ radical, formed from hydrogen peroxide $\left(\mathrm{H}_{2} \mathrm{O}_{2}\right)$ via Fenton's reaction, which could consequently degrade membrane lipids, generates peroxyl and alkoxyl radicals, and favour propagation of lipid oxidation (Akomolafe et al., 2015; Adedayo et al., 2015a, b). In this study, the extract caused a remarkable reduction in the TBARS produced, the effect that could be linked to the phenolic contents (Table 1 and 2).

Scavenging/chelation of free radicals and transition metals have been reported as some of the mechanisms by which antioxidant compounds could protect the cells/biomolecules from radical/metal induced oxidative damage (Valko et al., 2005; Flora, 2009; Kedare and Singh, 2011; Khan and Awan, 2014). To unravel some possible mechanisms by which the studied extract inhibits $\mathrm{Fe}^{2+}$ induced TBARs production in testicular tissues homogenate, the radicals $\left(\mathrm{DPPH}^{*}\right.$ and $\left.\mathrm{ABTS}^{*+}\right)$ scavenging and $\mathrm{Fe}^{2+}$ chelating abilities of the extract were assessed. Both $\mathrm{DPPH}^{*}$ and $\mathrm{ABTS}^{*+}$ scavenging assay methods are based on spectrophotometry and are commonly used to determine the 
antioxidative ability of natural extracts based on their ability to scavenge/reduce the radical cation ( $\operatorname{Re}$ et al., 1999; Kedare and Singh, 2011; Skotti et al., 2014). Several reports have revealed that excessive production of free radicals or ROS is one of the causes of male infertility which could be due to their deleterious effect on testes integrity/function (Aitken and Roman, 2008; Sankako et al., 2012; Agarwal et al., 2014). From our results, the assay on DPPH and ABTS radical scavenging abilities revealed that the extract could scavenge radicals. The result further revealed that the extract also chelated $\mathrm{Fe}^{2+}$ in a dose dependent manner. The radicals scavenging and $\mathrm{Fe}^{2+}$ chelating abilities could be among the mechanism of actions by which the studied extract prevented productions of TBARs, which if left uncheck could induce OS in the body (Adedayo et al., 2015a). The reducing power of the extract, expressed as ascorbic acid equivalent (AAE) could be via electron and/or hydrogen atom transfer ability of the phenolic compounds present in the extract (Chen et al., 2013; Al-Fartosy and Abdulwahid, 2015).

According to Allhorn et al (2005), ability of plant/food extract or natural compound to reduce metals could be a pointer to it potent anti-oxidation defense mechanism. Therefore, the polyphenolic compounds The reducing power of the extract, expressed as ascorbic acid equivalent (AAE) could be via to function as good electron/hydrogen atoms donor. Hence, the reducing power of the extract may have contributed to its protective effect observed.

\section{CONCLUSION}

In this study, the extract from the $C$. pepo fruit's pulp was able to prevent/inhibit $\mathrm{Fe}^{2+}$ induced TBARS production in the rat testes homogenate in vitro. This ability could be as a result of its radicals scavenging and $\mathrm{Fe}^{2+}$ abilities, and ability to reduce $\mathrm{Fe}^{2+}$ to $\mathrm{Fe}^{3+}$. Consequently, it could be linked to the presence of polyphenolic compounds. However, further in vivo and clinical study should be carried out.

\section{Financial support and sponsorship: Nil. \\ Conflict of Interests: There are no conflicts of interest.}

\section{REFERENCES}

Abd-Elmoaty MA, Saleh R, Sharma R, Agarwal A. Increased levels of oxidants and reduced antioxidants in semen of infertile men with varicocele. Fertility and Sterility, 2010; 94:15311534.

Adedayo BC, Oboh G, Oyeleye SI, Ejakpovi II, Boligon AA, Athayde ML. Blanching alters the phenolic constituents and in vitro antioxidant and anticholinesterases properties of fireweed (Crassocephalum crepidioides Journal of Taibah University Medical Sciences, 2015; 10(4):419-426.

Adedayo BC, Oyeleye SI, Ejakpovi II, Oboh G. Effects of hot water treatment on the radicals scavenging, lipid peroxidation, and $\alpha$-amylase and $\alpha$-glucosidase inhibitory abilities of Crassocephalum crepidioides leaves. Nutrafoods, 2015a; 14:217-225.

Ademiluyi AO, Oboh G, Boligon AA, Athayde ML. Effect of fermented soybean condiment supplemented diet on $\alpha$-amylase and $\alpha$ glucosidase activities in Streptozotocin-induced diabetic rats. Journal of Functional Foods, 2014; 31:1-9.
Agarwal A, Virk G, Ong C, Plessis SS. Effect of Oxidative Stress on Male Reproduction. The World Journal of Men's Health, 2014; 32:1-17.

Aitken RJ, Roman SD. Antioxidant systems and oxidative stress in the testes. Oxidative Medicine and Cellular Longevity, 2008; $1: 15-24$.

Akomolafe SF, Oboh G, Akindahunsi AA, Afolaya AJ. Tetracarpidium conophorum (Mull.Arg) Hutch \& Dalziel inhibits $\mathrm{FeSO}_{4-}$ induced lipid peroxidation in rat's genitals. BMC Complementary and Alternative Medicine, 2015; 15:57.

Al-Fartosy AJ, Abdulwahid AA. Antioxidant activity of anthocyanins extracted from Iraqi Iresine herbstii L. flowers after drying and freezing. American Journal of Analytical Chemistry, 2015; 6: 382.

Allhorn M. Klapyta A, Åkerström B. Redox properties of the lipocalin $\alpha 1$ microglobulin: reduction of cytochrome $\mathrm{C}$, hemoglobulin, and free iron. Free Radical Biology and Medicine, 2005; 38:557-567.

Atangwho IJ, Egbung GE, Ahmad M, Yam MF, Asmawi MZ. Antioxidant versus anti-diabetic properties of leaves from Vernonia amygdalina Del. growing in Malaysia. Food Chemistry, 2013; 141: 34283434.

Belle NAV, Dalmolin GD, Fonini G, Rubim MA, Rocha JBT. Polyamines reduce lipid peroxidation induced by different pro-oxidant agents. Brain Research, 2004; 1008:245-251.

Nwanna, E.E, Oyeleye, S.I, Ogunsuyi, O.B, Oboh, G, Boligon, A.A. Athayde, M.L. In vitro neuroprotective properties of some commonly consumed green leafy vegetables in Southern Nigeria. NFS Journal, 2016; 2: $19-24$.

Chen, XX, Wu XB, Chai WM, Feng HL, Shi Y, Zhou HT, Chen QX. Optimization of extraction of phenolics from leaves of Ficus virens. Journal of Zhejiang University Science B, 2013; 14:903-915.

Chu Y, Sun J, Wu X, Liu RH. Antioxidant and antiproliferative activity of common vegetables. Journal of Agricultural and Food Chemistry, 2002; 50:6910-6916.

Dai J, Mumper RJ. Plant phenolics: Extraction, Analysis and Their Antioxidant and Anticancer Properties. Molecules, 2010; 15:7313-52.

Dryden GW, Song M, McClain C. Polyphenols and gastrointestinal diseases. Current Opinion in Gastroenterology, 2006; 22:165.

Farombi EO, Olatunde O. Antioxidative and chemopreventive properties of Vernonia amygdalina and Garcinia biflavonoid. International Journal of Environmental Research and Public Health, 2011; 8:2533-2555.

Fasakin CF, Udenigwe CC, Aluko RE. Antioxidant properties of chlorophyll-enriched and chlorophyll-depleted polyphenolic fractions from leaves of Vernonia amygdalina and Gongronema latifolium. Food Research International, 2011; 44:2435-2441.

Flora SJS. Structural, chemical and biological aspects of antioxidants for strategies against metal and metalloid exposure. Oxidative Medicine and Cellular Longevity, 2009; 2:191-206.

Gacche RN, Kabaliye VN, Dhole NA and Jadha AD. Antioxidant potential of selected vegetables commonly used in diet in Asian subcontinent. Indian Journal of Natural Products and Resources,. $2010 ; 1: 306-313$

Gyamfi MA, Yonamine M, Aniya Y, Free-radical scavenging action of medicinal herbs from Ghana Thonningia sanguinea on experimentally-induced liver injuries. General Pharmacology: The Vascular System, 1999; 32:661-667.

Handique JG, Boruah MP, Kalita D. Antioxidant activities and total phenolic and flavonoid contents in three indigenous medicinal vegetables of north-east India. Natural Product Communications, 2012;7:1021-1023.

Ishikawa T, Fujioka H, Ishimura T, Takenaka A, Fujisawa M. Increased testicular 8-hydroxy-2'-deoxyguanosine in patients with varicocele. BJU International, 2007; 100:863-866.

Kedare SB, Singh RP. Genesis and development of DPPH method of antioxidant assay. J Journal of Food Science and Technology, $2011 ; 48(4): 412-422$.

Kelley WI, Coffey DL, Mueller TC. Liquid chromatographic determination of phenolic acids in soil. ournal of AOAC International, 1994; 77:805-809. 
Khan AR, Awan FR. Metals in the pathogenesis of type-2 diabetes. Journal of Diabetes and Metabolic Disorders, 2014; 13:16.

Köksal IT, Tefekli A, Usta M, Erol H, Abbasoglu S, Kadioglu A. The role of reactive oxygen species in testicular dysfunction associated with varicocele. BJU International, 2000; 86:549-552.

Meda A, Lamien CE, Romito M, Millogo J, Nacoulma OG. Determination of the total phenolic, flavonoid and proline contents in Burkina Faso honey, as well as their radical scavenging activity. Food Chemistry, 2005; 91:571-577.

Mostafa T, Anis T, Imam H, El-Nashar AR, Osman IA. Seminal reactive oxygen species-antioxidant relationship in fertile males with and without varicocele. Andrologia 2009; 41:125-129.

Nowotny K, Jung T, Höhn A, Weber D, Grune T. Advanced glycation end products and oxidative stress in type 2 diabetes mellitus. Biomolecules, 2015; 5:194-222.

Ohkawa H, Ohishi N, Yagi K. Assay for lipid peroxides in animal tissues by thiobarbituric acid reaction. Analitical Biochemistry. 1979; 95:351-358.

Oloyede FM. Growth, yield and antioxidant profile of pumpkin (Cucurbita pepo L.) Leafy vegetable as affected by NPK compound fertilizer. Journal of Soil Science and Plant Nutrition, 2012; 12:379-387.

Oyaizu M. Studies on products of browning reaction: antioxidative activity of products of browning reaction prepared from glucosamine. Japanese Journal of Nutrition, 1986; 44:307-315.

Pandey BK, Rizvi IS. Plant polyphenols as dietary antioxidants in human health and disease Oxid Med Cell Longev, 2009; 2:270-278.

Provan GL. Scobbie L, Chesson A. Determination of phenolic acids in plant cell walls by microwave digestion. Journal of the Science Food and Agriculture, 1994; 64:63-65.

Puntel RL, Nogueira CW, Rocha JBT. Krebs cycle intermediates modulate thiobarbituric reactive species (TBARS) production in Rat Brain In vitro.

Neurochemical Research, 2005; 30:225-235.

Radojkovic MM, Zekovic ZP, Vidovic SS, Kocar DD, Maškovic PZ. Free radical scavenging activity and total phenolic and flavonoid contents of mulberry (Morusspp. L., Moraceae) extracts. Hemijska industrija, 2012; 66:547-552.

Re R, Pellegrini N, Proteggente A, Pannala A, Yang M, RiceEvans C. Antioxidant activity applying an improved ABTS radical cation decolorisation assay. Free Radical Biology and Medicene, 1999; 26:1231-1237.
Sankako MK, Garcia PC, Piffer RC, Dallaqua B, Damasceno DC. Pereira OCM. Possible mechanism by which zinc protects the testicular function of rats exposed to cigarette smoke. Pharmacology Reports, 2012; 64:1537-1546.

Sarkar S, Guha D. Effect of ripe fruit pulp extract of Cucurbita pepo Linn. In aspirin induced gastric and duodenal ulcer in rats. Indian Journal of Experimental Biology, 2008; 48:639-645.

Schiffrin EL. Antioxidants in hypertension and cardiovascular diseases. Mol Inter, 2010; 10:354-362.

Singleton VL, Orthofor R, Lamuela-Raventos RM. Analysis of total phenols and other oxidation substrates and antioxidants by means of Folin-Ciocalteau reagent. Methods in Enzymology, 1999; 299:152-178.

Skotti E, Anastasaki E, Kanellou G, Polissiou M, Tarantilis PA. Total phenolic content, antioxidant activity and toxicity of aqueous extracts from selected Greek medicinal and aromatic plants. Industrial Crops and Product, 2014; 53:46-54.

Tsao R. Chemistry and Biochemistry of Dietary Polyphenols. Nutr, 2010; 2: 1231-1246.

Tulio AZ, Jablonski JE, Jackson LS, Chang C, Edirisinghe I, Burton-Freeman B. RETRACTED: Phenolic composition, antioxidant properties, and endothelial cell function of red and white cranberry fruits. Food Chemistry, 2014; 157:540-152.

Valko M, Morris H, Cronin MTD. Metals, Toxicity and Oxidative Stress. Current Medicinal Chemistry, 2005; 12:1161-1208.

Yagi K. Simple procedure for specific assay of lipid hydroperoxides in serum or plasma. Free Radical and Antioxidant Protocols 1998; 108:107-110.

\section{How to cite this article:}

Akomolafe SF, Oboh G, Oyeleye SI, Molehin OR, Ogunsuyi OB. Phenolic Composition and Inhibitory Ability of Methanolic Extract from Pumpkin (Cucurbita pepo L) Seeds on Fe-induced Thiobarbituric acid reactive species in Albino Rat's Testicular Tissue In-Vitro. J App Pharm Sci, 2016; 6 (09): 115-120. 